\title{
Detection of Shiga Toxin-Producing Escherichia coli (STEC) from Smoked Pork sold in Local Markets of Aizawl, Mizoram (India)
}

\author{
G. J. Lallawmkimi*, E. Motina, L. Ralte and J. Lalmuanpuia \\ Department of Veterinary Public Health and Epidemiology, C.V.Sc and A.H., \\ Selesih, Aizawl, Mizoram - 796014, India \\ *Corresponding author
}

\section{A B S T R A C T}

Keywords

Fecal contamination of agri-food,

Environment, Water chain

Article Info

Accepted:

10 January 2021

Available Online:

10 February 2021
E. coli is recognised as a major pathogen of public health significance in developing countries and represents the leading etiological agent of diarrhoea. The presence of $E$. coli in food or water is an indication of uncleanliness and careless handling and also implies the presence of enteric pathogens. The Shiga Toxin-Producing Escherichia coli (STEC) are public health food pathogens. STEC is responsible for human diseases ranging from mild diarrhoea to hemorrhagic colitis (HC) and life-threatening hemolytic uremic syndrome (HUS), leading to kidney failure and death, both in outbreaks and intermittent events.

\section{Introduction}

Food protection has become a key issue in fresh products worldwide because of many factors, such as the import of fresh products from different countries, possible sources of increasing bacterial pathogens and poor domestic preparation (Wang et al., 2020).

In the human gut, Escherichia coli is a part of the normal flora, but some strains they are pathogenic (Kim et al., 2020). STEC is critical for public health, potentially causing diarrhoea, bloody diarrhoea (hemorrhagic colitis), hemolytic uremic syndrome (HUS) and kidney injury (Castro et al., 2019). STECproduced toxins are categorised as type 1 (Stx1) and type 2 (Stx2) and several subtypes and variants of Stx $1 / \mathrm{Stx} 2$ have been identified on the basis of receptor preference and toxin potency (Melton-Celsa, 2014).

The transmission of STEC can happen by various routes, through food (Frank et al., 2011), fecal contamination of agri-food, the environment, or the water chain (Rothenburger et al., 2017), person to person contact (Rowe et al., 1993), animals such as cattle (Ferens and Hovde, 2011), swine (Gyles, 2007) etc. 


\section{Materials and Methods}

A total of 200 smoked porks were collected from different local markets of Aizawl, Mizoram, India. All the swabs were processed for isolation and identification of E.coli (Ewing, 1986). All the isolates were further assessed by polymerase chain reaction (PCR) assay for the presence of putative virulence gene(s) $\left(s t x_{1}\right.$ and $\left.s t x_{2}\right)$ (Paton and Paton, 1998). All the isolates were then subjected to antimicrobial sensitivity assay by disc diffusion method using 14 commonly used antimicrobial agents (Bauer et al., 1966).

\section{Results and Discussion}

A total of $30 \mathrm{E}$. coli were isolated, of which 10 (33.33\%) isolates were found to be positive for at least one virulence gene (Table 1) of STEC. As depicted in Table 1, a total of 2 $(6.66 \%)$ and $1(3.33 \%)$ isolates were positive for $s t x_{1}$ and $s t x_{2}$ genes and $2(6.66 \%)$ isolates for $s t x_{1}$ and $s t x_{2}$ genes combination. Among the STEC isolates, stx $2(22.66 \%)$ was predominant over $s t x_{1}(6.66 \%)$ which was in accordance to the findings of earlier workers (Omoruyi et al., 2018; Kataria et al., 2017). Detection of $s t x_{2}$ positive isolates from smoked pork may result in a public health concern as in a murine infection model, shiga toxin 2 is reportedly 400 times more toxic than Stx 1 and shiga toxin 2 is more frequently related to complications of HUS than Stx1 (Shridhar et al., 2017).

For $s t x_{2}$ and eaeA, stx $x_{2}$ and $h l y \mathrm{~A}, s t x_{2}$ and eaeA and hlyA combinations 1(3.33\%), $2(6.66 \%)$ and $2(6.66 \%)$ isolates were positive respectively. A total of $7(23.33 \%)$ isolates were carrying multiple genes. The key virulence factors of STEC are shiga toxins formed by the $s t x_{1}$ and $s t x_{2}$ genes, while the eaeA gene, which codes for intimate protein, mediates STEC's attachment to the enterocytes. HUS is mostly associated with STEC strains carrying the genes $s t x_{2}$ and eae $\mathrm{A}$, and this composition of the gene is known to be a high risk of developing HUS (Loconsole et al., 2020).

Table.1 STEC virulence gene(s) profile in smoked pork from local market in Aizawl, Mizoram

\begin{tabular}{|c|c|c|}
\hline Sl. no & Virulence (STEC) & Total $(\mathbf{n}=30)$ \\
\hline $\mathbf{1}$ & $s t x_{1}$ only & $2(6.66 \%)$ \\
\hline $\mathbf{2}$ & $s t x_{2}$ only & $1(3.33 \%)$ \\
\hline $\mathbf{3}$ & $s t x_{1}$ and $s t x_{2}$ & $2(6.66 \%)$ \\
\hline $\mathbf{4}$ & $s t x_{2}$ and $e a e \mathrm{~A}$ & $1(3.33 \%)$ \\
\hline $\mathbf{5}$ & $s t x_{2}$ and $h l y \mathrm{~A}$ & $2(6.66 \%)$ \\
\hline $\mathbf{6}$ & $s t x_{2}, e a e \mathrm{~A}$ and $h l y \mathrm{~A}$ & $2(6.66 \%)$ \\
\hline
\end{tabular}

All the 10 STEC isolates showed $100 \%$ drug resistance to erythromycin, and amoxicillin. Imepenem, amoxyclav and ceftriaxone were the better antimicrobial agents in terms of sensitivity. Multiple drug resistance can result from propagation in STEC strains. The transmission of horizontal elements within and among bacterial species, such as plasmids, prophages or transposons, is predominantly possible in environments like the gut microbiome (Amaechi et al., 2015).

The key source of protein in Mizoram is pork and the development of high-proportion multidrug-resistant STEC isolates may constitute a significant reservoir that poses a risk to public 
health and may complicate potential therapeutic options.

\section{Acknowledgement}

The author are thankful to Dean, College of Veterinary Science and Animal Husbandry, Central Agricultural University, Selesih, Aizawl, Mizoram, India for providing necessary funds and facilities to carry out the investigation.

\section{References}

Amaechi. N., Abbey, S.D. and Achi,O.K. 2015. Plasmid Profile and Antimicrobial Resistance Ratings of Escherichia coli Isolates from Pigs and Poultry Birds in Abia State, Nigeria. Int. J. Curr. Microbiol. App. Sci., 2: 834-842.

Bauer, A.W., Kirby, W.M., Sherriz, J.C. and Tuck, N. $1966 . \quad$ Antibiotic susceptibility testing by standardized single disc method. Am. J. Clin. Pathol., 45: 493-496.

Castro, V.S., Figueiredo, E.E., Stanford, K., McAllister, T. and Junior, C.A. 2019. Shiga-Toxin Producing Escherichia coli in Brazil: A Systematic Review. Microorg., 9(7): 137

Ewing, W. H. (1986). The genus Escherichia,p. 93-122. In P. R. Edwards and W. H Ewing (ed), Edwards and Ewing's identification of Enterobacteriaceae, $4^{\text {th }}$ ed. Elsevier Science Publishing Co Inc., New York, N. Y.

Ferens, W.A. and Hovde, C.J. 2011. Escherichia coli O157:H7: animal reservoir and sources of human infection. Foodborne Pathog. Dis., 8:465-487.

doi: 10.1089/fpd.2010.0673.

Frank, C., Werber, D., Cramer, J.P., Askar, M., Faber, M., An Der Heiden, M.,
Bernard, H., Fruth, A., Prager, R., Spode, A., Wadl, M., Zoufaly, A., Jordan, S., Stark, K. and Krause, G. 2011. Epidemic profile of Shiga-toxinproducing Escherichia coli O104:H4 outbreak in Germany. N. Engl. J. Med., 365: 1771-1780. doi: 10.1056/NEJMoa1 106483.

Gyles, C.L. 1999. Associations between virulence factors of Shiga toxin producing Escherichia coli and disease in humans. J. Clin. Microbiol., 37: 497-503. doi: 10.1128/JCM.37.3.497503.1999 .

Kataria, J.L., Datta, T.K. and Roychoudhury, P. 2017. Virulence gene(s) gamut of Entero Pathogenic Escherichia coli (EPEC) and Shiga Toxin-Producing Escherichia coli (STEC) in Piglets With or Without Diarrhoea in Mizoram (India). Int. J. Curr. Microbiol. App.Sci., 6(11): xxxx. doi: https://doi.org/10.20546/ijcmas.2017.6 11.xx

Kim, J.S., Lee, M.S. and Kim, J.H. 2020. Recent Updates on Outbreaks of Shiga Toxin-Producing Escherichia coli and Its Potential Reservoirs. Front. Cell. Infect. Microbiol., 10:273. doi: 10.3389/fcimb.2020.00273.

Loconsole, D., Giordano, M., Centrone, F., Accogli, M., Casulli, D., Robertis, A.L., Morea, A., Quarto, M., Parisi, A., Scavia, G. and Chironna, M. 2020. Epidemiology of Shiga ToxinProducing Escherichia coli Infections in Southern Italy after Implementation of Symptom-Based Surveillance of Bloody Diarrhea in the Pediatric Population. Int. J. Environ. Res. Pub. Hlth., 17: 5137; doi: 10.3390/ijerph17145137.

Melton-Celsa, A.R. 2014. Shiga toxin (Stx) classification, structure and function. Microbiol. Spectr. 2: EHEC-00242013.doi: 
10.1128/microbiolspec.EHEC-00242013.

Omoruyi, I.M., Uwadiae, E., Mulade, G. and Omoruku, E. 2018. Shiga Toxin Producing Strains of Escherichia coli (STEC) Associated with Beef Products and Its Potential Pathogenic Effect. Microbiol. Resch. J. Int., 23(1): 1-7, 2018; Article no.MRJI.32959. ISSN: 2456-7043.

Paton, J.C., and Paton, A.W. 1998. Pathogenesis and diagnosis of Shiga toxin-producing Escherichia coli infections. Clin. Microbiol. Rev., 11: 450-479.

Rothenburger, J.L., Himsworth, C.H., Nemeth, N.M., Pearl, D.L. and Jardine, C. M. 2017. Environmental factors and zoonotic pathogen ecology in urban exploiter species. Eco. Hlth., 14:
630-641. doi: 10.1007/s10393-0171258-5.

Rowe, P.C., Orrbine, E., Lior, H., Wells, G.A. and McLaine, P.N. 1993. Diarrhoea in close contacts as a risk factor for childhood haemolytic uraemic syndrome. Epi. Infect., 110:9-16.

Shridhar, P.B., Siepker, C., Noll, L.W., Shi, X., Nagaraja, T.G. and Bai, J. 2017. Shiga Toxin Subtypes of Non-O157 Escherichia coli Serogroups Isolated from Cattle Feces. Front. Cell. Infect. Microbiol., 7:121. doi: 10.3389/fcimb.2017.00121.

Wang, Y.J., Deering, A.J. and Kim, H.J. 2020. The Occurrence of Shiga ToxinProducing E. coli in Aquaponic and Hydroponic Systems. Horti., 6(1): doi:10.3390/horticulturae6010001.

\section{How to cite this article:}

Lallawmkimi, G. J., E. Motina, L. Ralte and Lalmuanpuia, J. 2021. Detection of Shiga ToxinProducing Escherichia coli (STEC) from Smoked Pork Sold in Local Markets of Aizawl, Mizoram (India). Int.J.Curr.Microbiol.App.Sci. 10(02): 1246-1249. doi: https://doi.org/10.20546/ijcmas.2021.1002.146 